\title{
Odonata next-door: an updated check-list of two parks in the Northern Milan outskirt (Lombardy, Italy)
}

\author{
Claudio Foglini
}

\begin{abstract}
Odonata are usually regarded as bioindicators and model organisms in many studies and are subjected to increasing threats worldwide. Such insects populate freshwater ecosystems at both natural and urban landscapes and they are also well-known by common people. This work is aimed at summarizing and updating the current knowledge concerning Odonata species inhabiting two parks located at the northern boundary of the Milan outskirts (Italy, Lombardy). Occupancy status for odonate species were obtained merging the field data of surveys conducted during 2014 and 2015 with spare information from specialistic websites and forums, grey literature, and pictures collected at the same sites by occasional observers. The total number of species found in both parks showed an increase of species richness when compared with two previous studies. Morevoer, Odonata communities of the two parks showed a common chorological composition and similarity in the species assemblages. This work had also a positive impact about the perception of urban biodiversity: some of the untrained observers, who shared their pictures for species identification, rapidly acquired sufficient knowledge to easily recognize the most common species present in both parks.
\end{abstract}

Key words: Periurban parks, Urban biodiversity, Wetlands.

Riassunto - Odonati: check-list aggiornata di due parchi dell'hinterland Nord di Milano (Lombardia, Italia).

Gli odonati sono utilizzati come bioindicatori e organismi modello in numerosi studi, ed a livello globale sono soggetti a numerose minacce. In aggiunta, poiché popolano anche numerosi ambienti acquatici anche in ambiente urbano, sono tra gli insetti più conosciuti anche tra le persone comuni. Questo lavoro è mirato a ricapitolare ed aggiornare la conoscenza rigurardo alle specie di odonati presenti in due parchi situati nell'hinterland Nord di Milano (Italia, Lombardia). I dati sulla presenza delle specie rinvenute sono stati ottenuti unendo i risultati dei rilievi di campo condotti dall'autore nel 2014 e nel 2015 con informazioni reperite da siti e forum web specialistici, letteratura grigia, fotografie inviate da osservatori occasionali. Il nuovo numero totale di specie per entrambi i parchi è stato confrontato con due precedenti pubblicazioni, e ha mostrato un incremento nella ricchezza specifica, evidenziando al contempo una composizione corologica comune ed una buona similarità tra i due siti. Questo lavoro ha ottenuto inoltre un impatto positivo sulla percezione della biodiversità urbana dei luoghi: alcuni degli osservatori occasionali che hanno inviato le proprie

Via Leon Battista Alberti 8/A, 20092 Cinisello Balsamo (MI), Italia

E-mail: clafogli@libero.it

(C) 2016 Claudio Foglini

Received: 29 April 2016

Accepted for publication: 11 July 2016 foto per chiedere un'identificazione della specie ritratta, sono ora in grado di riconoscere almeno le principali specie di odonati presenti nei parchi oggetto di studio.

Parole chiave: Aree umide, Biodiversità urbana, Parchi periurbani.

\section{INTRODUCTION}

Odonata is a well studied insect group (Kalkman et al., 2010), often used as bioindicator (Chovanec, 1994; Sahlen \& Ekkestubbe, 2001; Briers \& Biggs, 2003) and its members are commonly employed as model organisms in short (e.g., conservation biology and alteration of freshwater ecosystems) and long terms (e.g., biogeography and climatology) studies (Córdoba-Aguilar, 2008; Kalkman et al., 2010). Odonata are indeed characterized by a well-known and stable taxonomy, ease of identification, known biology, and sensitivity to chemical, physical and biological changes in water systems (Hodginson \& Jackson, 2005; Burger, 2006; Bried et al., 2007; Everard, 2008). In freshwater ecosystems, Odonata are subjected to conservation threats such as habitat loss, alteration and pollution (Clausnitzer et al., 2009; Bried \& Mazzacano, 2010; Kalkman et al., 2010), whereas in urban landscapes many species are pioneers in colonizing artificial lakes, ponds and ditches in gardens and urban parks (Oertli, 2008; Dutta Saha \& Gaikwad, 2014). Moreover, odonates are well known animals among people due to their widespread distribution, conspicuous habits and striking colours (Riservato et al., 2014). Their appeal has led to the publication of various field guides (Askew, 2004; Dijkstra \& Lewington, 2006; Boudot \& Kalkman, 2015; Galliani et al., 2015), local distribution atlas (Boano et al., 2007; Hardensen, 2007; Riservato, 2009; Dalla Via \& Zanetti, 2015) or species inventories (many of them as grey literature, partly available on the web).

This work is aimed at updating the list of Odonata species hosted in the freshwater ecosystems of two parks in the North outskirts of Milan (Lombardy, Italy).

\section{MATERIALS AND METHODS}

This survey was carried out in the Lombardy region, northern Italy, into a human landscape dominated mainly by large cities and scattered agricultural areas. Several parks protect the few residual natural habitats, with the 
final goal of creating and maintaining a Regional Ecological Network (Rete Ecologica Regionale Lombarda; Bogliani et al., 2007). Two key elements of this ecological network are the parks Nord Milano and the GrugnotortoVilloresi (Fig. 1).

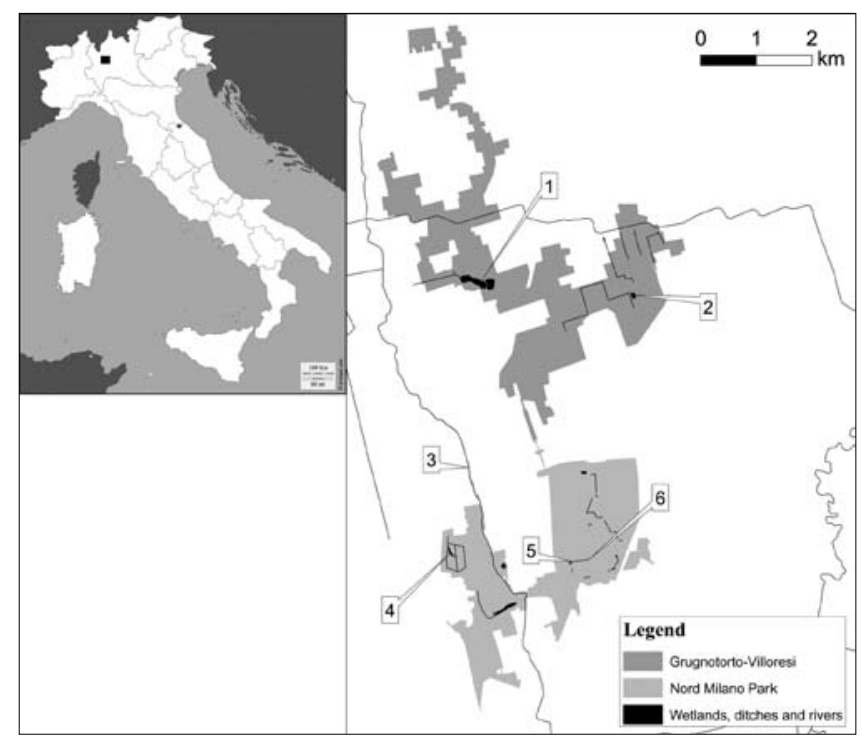

Fig. 1 - Study area (Lombardy region, Northern Italy). Numbers in flags indicate wetlands: 1) Lago Nord Park; 2) S. Eusebio protected area; 3) Seveso River; 4) Bruzzano Lake; 5) Bresso-Leopardi Lake; 6) Bresso Lake (modified from www.d-maps.com and GeoPortale Regione Lombardia).

Nord Milano Park is a periurban Regional park (640 ha) located in the North outskirts of Milan. It was created on the Breda's factory brownfield, during the later sixties, and the first reforestations dates back to 1983. During years, meadows and lawns, artificial wetlands, small lakes and ditches were added along with woods. Many others environmental improvement measures are still in progress. The current freshwater system is composed by seven lakes (a pair of them connected), running water ditches and a few ponds.

The Grugnotorto-Villoresi is a local park of extramunicipal interest ( $880 \mathrm{ha}$ ), about $10 \mathrm{~km}$ north from the Milan city centre, and is mainly composed by s residual agricultural landscape scattered within the urban matrix. Major wetlands are represented by an artificial small lake in the South-East portion (S. Eusebio protected area), and two lakes derived from a quarry now converted into a protected area with fishing activities, wetlands and green recreation areas (Lago Nord Park).

Field survey of Odonata was conducted by the author during 2014 and 2015, from May to October. Adult insects in both parks were recorded walking at slow pace along lakes, ponds edges and surroundings during sunny days, four times per month, randomly for 2 hours, between 09:00 AM and 16:00 PM, when odonate activity is at maximum (Sutherland, 1996). Flying and perching adults were identified in the field with the aid of binoculars, according to Dijkstra \& Lewington (2006) and Galliani et al., (2015). Some species were identified after the exa- mination of pictures taken by DSLR (Canon 50D) with macro (Canon 100/2.8L IS USM) or telephoto (Canon 400/5.6 IS L) lenses (Canon, Tokyo, Japan). Additional observations were collected by members of the park's mailing list (BWparconordmilano@yahoogroups.it),who shared their pictures and observations taken during excursions in both parks. Additional data were added after a bibliographical research on official reports and publications, web forum for photographers and entomologists, or simply typing the words "odonates" or "dragonflies" (in Italian) combined with "Parco Nord Milano" and "Grugnotorto" on Google ${ }^{\circledR}$. Observations were confirmed only in presence of good-quality pictures and exhaustive indications of the location. Due to the need of merging such different data sources, only site occupancy information (presence/absence) was used.

A comparison between the two odonates communities was performed with BioDiversity Pro v.2 (McAleece et al., 1997).

For both parks, the author considered as starting list the work published in Casale et al., (2012) and its update (Foglini, 2013).

\section{RESULTS}

At the end of the work, a total of 25 species (7 Zygoptera and 18 Anisoptera) was recorded in the Nord Milano Park. In the Grugnotorto-Villoresi Park, the total was of 22 species (7 Zygoptera and 15 Anisoptera). The complete list is shown in Appendix 1.

Species composition of the two odonates communities showed a Jaccard similarity value of $74.07 \%$ (cluster method, single linkage).

According to the biogeographical classification (adapted from Ottonello \& Oneto, 2013), both communities were mainly composed by Palearctic species, in particular West Palearctic and Eurosibiric ones, followed by Submediterranean and Afro-European species for the Nord Milano Park, whereas in the Grugnotorto-Villoresi Park Afro-European species were more abundant than Submediterranean ones (Fig. 2).

Comparing the cumulative species number reported in Casale et al., (2012) and Foglini (2013), in this work an increasing trend of species richness at both parks can be observed, although not all species have been recorded during each year of study (Fig. 3).

\section{New species in the Nord Milano Park}

Lestes sponsa (Hansemann, 1823): photographed in 2010 by C. Galliani (http://www.entomologiitaliani.net/ public/forum/phpBB3/viewtopic.php?t=12000) in the Northern sector of the park, but not listed in Casale et al., (2012). No further reports until October 2015, with only one male observed in the Bresso-Leopardi Lake (picture by M.R. Gelso, pers. comm.).

Erythromma viridulum (Charpentier, 1840): this specie was previously portrayed in the park during July 2012 (M. Molino, www.juzaphoto.com/p/Molly), but the observation was not confirmed because of unknown exact location. In June 2015, three individuals were observed by the author in a pond near the Bruzzano Lake. 


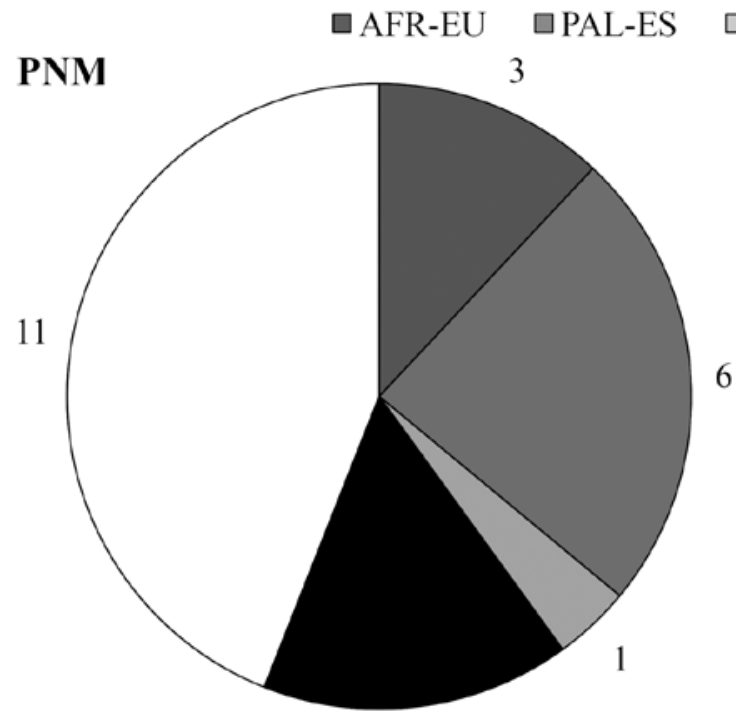

4

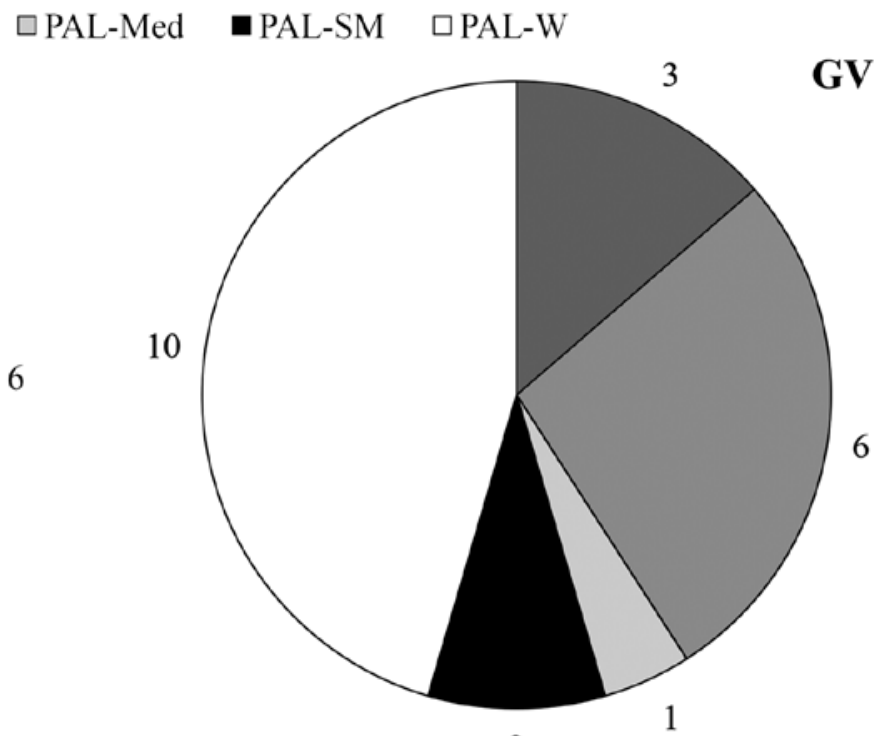

2

Fig. 2 - Odonata communities in both parks (PNM as Nord Milano Park; GV as Grugnotorto-Villoresi Park) at the end of this work (2015). Numbers indicate the sum of species for each chorological group with the following abbreviation: AFR-EU = Afro-European; PAL-ES = Palearctic-Eurosibiric; PAL-Med = Palearctic-Mediterranean; PAL-SM = Palearctic-Submediterranean; PAL-W = West Palearctic.

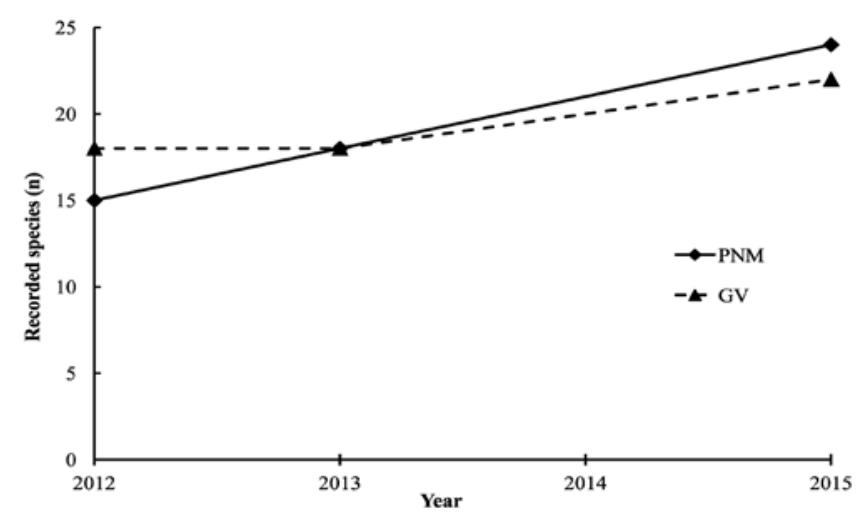

Fig. 3 - Trend of the overall species recorded at both parks (PNM as Nord Milano Park, GV as Grugnotorto-Villoresi Park).

Aeshna isosceles (Müller, 1767): An individual portrayed in June 2009 by F. Massaro (https://www.flickr.com/ photos/franco unico/3625989611/in/photostream/) at the Bresso-Leopardi Lake, but no further sightings occurred.

Anax parthenope (Selys, 1839): only one record by the author of an isolated individual, during August 2015, in a pond near the Bruzzano Lake.

Onychogomphus furcipatus (Linnaeus, 1758): only one record in July 2015, along the Seveso River (picture by T. Giglio, pers. comm.).

Libellula fulva (Müller, 1764): only one sighting in the Bresso Lake, in May 2015 (picture by M.R. Gelso, pers. comm.).

Sympetrum vulgatum (Linnaeus, 1758): unconfirmed because of a not resolutive picture (T. Giglio, pers. comm.).

\section{New species in the Grugnotorto-Villoresi Park}

Erythromma viridulum (Charpentier, 1840): previously portrayed in the park in 2012 (M. Molino, pers. comm.), but not confirmed due to the lack of the sighting location, and no further observation occurred.

Ischnura pumilio (Charpentier, 1825): recorded a few times by the author, during 2014 and 2015, in the Sant'Eusebio protected area.

Platycnemis pennipes (Pallas, 1771): one individual photographed once in August 2014, in the Sant'Eusebio protected area (A. \& M. Ghislandi, pers. comm.).

Somatochlora metallica (Vander Linden, 1825): one individual photographed in the Sant'Eusebio protected area once in August 2014 by A. \& M. Ghislandi (pers. comm.).

Orthetrum brunneum (Fonscolombe, 1837): observed by the author, during 2014 and 2015, in the Lago Nord Park.

\section{General notes}

Assessing the reproductive status of the species inhabiting both parks was beyond the aim of this work, because occasional observers were not trained in collecting the exuviae and there were no information about odonates breeding status in Casale et al. (2012). Otherwise, some speculations could be inferred from pictures or observations of breeding behaviours (such as mating, tandem, egg laying), or from the observation of teneral individuals.

Many species could be considered as breeding in both parks. Exuviae and egg-laying females of $A$. imperator (Leach, 1815) were common; few A. mixta (Latreille, 1805 ) adults were observed each year at the same stations, but only in the Grugnotorto-Villoresi Park with a mating couple.

Tandem and mating couples of damselflies such as $I$. elegans (Vander Linden, 1820) and C. puella (L., 1758) were usually present also in great numbers, but I. pumilio (Charpentier, 1825) was less common and observed only as adult. 
Tandems and juveniles of the Orthetrum and Sympetrum species recorded were also widely sighted.

L. depressa (L., 1758) and C. erythraea (Brullé, 1832) were commonly observed only as adults, but they were recorded each year at the same stations. $C$. viridis (Vander Linden, 1825) was less common (but probably underestimated) and reproductive in the Nord Milano Park (one mating couple observed), whereas a single observation occurred once in the Grugnotorto-Villoresi Park during the period covered by this study.

Adults of C. splendens (Harris, 1782), L. sponsa (Hansemann, 1823) and A. parthenope (Selys, 1839) were occasional sightings, whereas the status of $A$. cyanea (Müller, 1764) is still unknown.

Adults of P. pennipes (Pallas, 1771) and S. metallica (Vander Linden, 1825) were recorded only once in the Grugnotorto-Villoresi Park, as well as casual visitors could be considered isolated adult males of $O$. furcipatus (L., 1758), L. fulva (Müller, 1764) and A. isosceles (Müller, 1767) observed only once in the Nord Milano Park.

\section{DISCUSSION}

In urban landscapes, the creation of new water bodies is a frequently adopted measure in the framework of ecological network restoration practices (Oertli, 2008). As a matter of fact, small lakes and ponds attract many animal species and support more plant and macroinvertebrate species than rivers, streams, and ditches (Raebel et al., 2012).

Compared to the previous check-list (Foglini, 2013), the new one here presented shows six new species for the Nord Milano Park and four new species for the Grugnotorto-Villoresi Park. The putative occurrence of two other species (one for each study area, i.e. S. vulgatum and $E$. viridulum respectively) still needs more clarification for an undoubtful confirmation, so they were not included in the total count.

The species recorded in the two parks show that the artificial aquatic biotopes are inhabited mainly by a small number of common eurytopic species, as also reported by Samways (1994) and Wildermuth (1994). None of the recorded species (Appendix 1) was of particular conservation concern: all of them are rated as "Least Concern", according to European (Kalkman et al., 2010) and Italian (Riservato et al., 2014) IUCN Odonata Red List.

The low species diversity may probably be ascribed to the strong presence of Odonata larvae-eater fishes (Crowder \& Cooper, 1982; Morin, 1984; Johnson et al., 1995). Several alien predators species such as catfishes Ameiurus sp., pumpkinseed (Lepomis gibbosus L., 1758), largemouth bass (Micropterus salmoides Lacépède, 1802) and pike-perch (Sander lucioperca L., 1758) populate the lakes of both parks. Red swamp crayfishes (Procambarus clarkii Girard, 1852) and slider turtles (Trachemys scripta Schoepff, 1792) also occur. Noteworthy, P. clarkii was reported to exert a strong impact against juvenile aquatic stages of odonates with direct and indirect interactions (Siesa et al., 2014).
Because species inventories of adult odonates can easily be produced by volunteers or hobbyists, the drawback of such approach is a proliferation of works without standardization procedures (e.g. about sampling effort and abundance estimation) (Oertli, 2008) with scarce utility in the field of biodiversity conservation, but quite useful for divulgation purposes (Kadoya \& Washitani, 2007). As this work mixed fieldwork and indirect sources of information, for the same reasons, the positive trend in the cumulative species richness during years cannot only be addressed to natural colonization dynamics but could be due to the increasing number of occasional observers during years, or, ultimately, to environmental changes occurred at one or both the parks. In fact, during 2013, at least four different ditch systems and one lake were completed in the Nord Milano Park, followed by two additional lakes at the end of 2015.

On the other hand, the positive social attitude towards Odonata could be a key element to ensure the success of environmental restoration or improvement programs (Riservato et al., 2014), and to engage people in promoting ecological awareness (Primack et al., 2000). This could be especially true in urban landscape, where the lack of typical flagship or charismatic species, such as great mammals or predators, makes it more difficult to explain the way restoration practices work and how the public money is spent (Oertli, 2008). Concerning people involvement, some of the untrained observers who sent their pictures asking for species identification, after a few indications, are now able to identify at least the most common odonates recorded in both parks. This can be considered a meaningful success in promoting urban biodiversity conservation, especially in the study areas here investigated, where the only fauna usually known by common people is limited to mallard (Anas platyrhynchos L., 1758), slider turtles and hooded crows (Corvus cornix L., 1758).

Along with butterflies, dragonflies are probably the most significant invertebrates providing recreational services (Lemelin, 2007). The value of odonates is recognised worldwide in many parks, reserves and gardens with the creation of dedicated dragonfly trails and ponds, not purely for the conservation of endangered species, but also for the enjoyment of hobbyists, entomologists and photographers (Suh \& Samways, 2001; Niba \& Samways, 2006), also in Italy (Parco Regionale Adda Sud and Bosco della Giretta natural reserve, both in Lombardy).

\section{Acknowledgments}

I wish to thank Marco Siliprandi, promoter of the mailing list BWparconordmilano@yahoogroups.it, and all people who shared their sightings and pictures, particularly (in alphabetical order): Maria Rita Gelso, Anna and Maurizio Ghislandi, Thomas Giglio, Franco Massaro. Many thanks to Stefano Aguzzi for helpful suggestions about identification of some species, and also to Erika A.V. Burioli and Andrea Galimberti for manuscript revision. 


\section{REFERENCES}

Askew R.R., 2004 - The Dragonflies of Europe, I edition. Harley Books, Compass Press Ltd, London.

Boano G., Sindaco R., Riservato E., Fasano S. \& Barbero R., 2007 Atlante degli Odonati del Piemonte e della Valle d'Aosta. Memorie dell'Associazione Naturalistica Piemontese, Savigliano, 6.

Bogliani G., Agapito Ludovici A., Arduino S., Brambilla M., Casale F., Crovetto G. M., Falco R., Siccardi P. \& Trivellini G., 2007 Aree prioritarie per la biodiversità nella Pianura Padana lombarda. Fondazione Lombardia per l'Ambiente e Regione Lombardia, Milano.

Boudot J.P. \& Kalkman V. (eds.), 2015 - Atlas of the European dragonflies and damselflies. KNNV Publishing, Netherlands.

Bried J.T., Herman B.D. \& Ervin G.N., 2007 - Umbrella potential of plants and dragonflies for wetland conservation: a quantitative case study using the umbrella index. Journal of Applied Ecology, 44: 833-842.

Bried J.T. \& Mazzacano C.A., 2010 - National review of state wildlife action plans for Odonata species of greatest conservation need. Insect Conservation and Diversity, 3: 61-71.

Briers R.A. \& Biggs J., 2003 - Indicator taxa for the conservation of pond invertebrate diversity. Aquatic Conservation: Marine and Freshwater Ecosystems, 13: 323-330.

Burger J., 2006 - Bioindicators: types, development, and use in ecological assessment and research. Environmental Bioindicators, 1: 22-39.

Casale F., Bergero V., Brambilla M., Campana F., Decarli M.L., Falco R., Gini R., Redondi A., Siliprandi M., Tucci R., Crovetto G.M. \& Bogliani G., 2012 - Atlante della biodiversità nelle aree protette del Nord Milanese. Fondazione Lombardia per l'Ambiente, Milano.

Chovanec A., 1994 - Libellen als Bioindikatoren. Anax 1: 1-9.

Clausnitzer V., Kalkman V.J., Ram M., Collen B., Baillie J.E.M., Bedjanič M., Darwall W.R.T., Dijkstra K.-D.B., Dow R., Hawking J., Karube H., Malikova E., Paulson D., Schütte K., Suhling F., Villanueva R., von Ellenrieder N. \& Wilson K., 2009 - Odonata enter the biodiversity crisis debate: the first global assessment of an insect group. Biological Conservation, 142: 1864-1869.

Córdoba-Aguilar A., 2008 - Dragonflies \& Damselflies. Model organisms for ecological and evolutionary research. Oxford University Press, New York.

Crowder L.B. \& Cooper W.W., 1982 - Habitat structural complexity and the interaction between bluegills and their prey. Ecology, 63: $1802-1813$.

Dalla Via M. \& Zanetti M., 2015 - Atlante delle Libellule della Pianura Veneta Orientale. ADLE edizioni, Padova.

Dijkstra K.D.B. \& Lewington R., 2006 - Field Guide to the Dragonflies of Britain and Europe. British Wildlife Publishing, Gillingham.

Dutta Saha P. \& Gaikwad S.M., 2014 - Diversity and abundance of Odonata in parks and gardens of Pune city. Journal of Entomology and Zoology Studies, 2 (5): 308-316.

Everard M., 2008 - Selection of taxa as indicators of river and freshwater wetland quality in the UK. Aquatic Conservation: Marine and Freshwater Ecosystems, 18: 1052-1061.

Foglini C., 2013 - Check-list degli odonati del Parco Nord Milano e del PLIS Grugnotorto-Villoresi (Agosto 2013). <http://www.parconord.milano.it/images/stories/fauna/insetti/Check-list_odonati_ Nord_Milano.pdf> (retrieved April 2016).

Galliani C., Scherini R. \& Piglia A., 2015 - Odonati d'Italia. Guida al riconoscimento e allo studio di libellule e damigelle. Libreria della Natura, Milano.

Hardensen S., 2007 - Le libellule di bosco della Fontana. Cierre Edizioni, Verona.

Hodkinson I.D. \& Jackson J.K., 2005 - Terrestrial and aquatic invertebrates as bioindicators for environmental monitoring, with particular reference to mountain ecosystems. Environmental Management, 35: 649-666.

Johnson D. M., Martin T.H., Mahato M., Crowder L.B. \& Crowley P. H., 1995 - Predation, density dependence, and life histories of dragonflies: a field experiment in a freshwater community. Journal of the North American Benthological Society, 14: 547562 .
Kadoya T. \& Washitani I., 2007 - An adaptive management scheme for wetland restoration incorporating participatory monitoring into scientific predictions using dragonflies as an indicator taxon. Global Environmental Research, 11: 179-185.

Kalkman V.J., Boudot J.P., Bernard R., Conze K.J., De Knijf G., Dyatlova E., Ferreira S., Jović M., Ott J., Riservato E. \& Sahlén G., 2010 - European Red List of Dragonflies. Publications Office of the European Union, Luxembourg.

Lemelin R.H., 2007 - Finding beauty in the dragon: The role of dragonflies in recreation, tourism, and conservation. Journal of Ecotourism, 6 (2): 139-145.

McAleece N., Gage J.D.G., Lambshead P.J.D. \& Paterson G.L.J., 1997 BioDiversity Professional statistics analysis software. Jointly developed by the Scottish Association for Marine Science and the Natural History Museum London (retrieved on 01/01/2016).

Morin P.J., 1984 - Odonate guild composition: experiments with colonization history and fish predation. Ecology, 65 (6): 1866-1873.

Niba A.S. \& Samways M.J., 2006 - Development of the concept of "core resident species" for quality assurance of an insect reserve. Biodiversity and Conservation, 15: 4181-4196.

Oertli B., 2008 - The use of dragonflies in the assessment and monitoring of aquatic habitats. In: Dragonflies \& Damselflies. Model organisms for ecological and evolutionary research. Córdoba-Aguilar A. (ed). Oxford University Press, New York: 79-95.

Ottonello D. \& Oneto F., 2013 - Libellule di Liguria (Odonata). Estratto dagli Annali del Museo Civico di Storia Naturale "G. Doria". Erredi Grafiche Editoriali, Genova, 105: 297-425.

Primack R., Kobori H. \& Mori S., 2000 - Dragonfly pond restoration promotes conservation awareness in Japan. Conservation Biology, 14: 1553-1554.

Raebel E.M., Merckx T., Feber R.E.,Riordan P., Macdonald D.W. \& Thompson D.J., 2012 - Identifying high-quality pond habitats for Odonata in lowland England: implications for agri-environment schemes. Insect Conservation and Diversity, 5 (6): 422-432.

Riservato E., 2009 - Atlante delle libellule della provincia di Novara. Provincia di Novara.

Riservato E., Fabbri R., Festi A., Grieco C., Hardersen S., Landi F., Utzeri C., Rondinini C., Battistoni A. \& Teofili C. (compilatori), 2014 - Lista Rossa IUCN delle libellule Italiane. Comitato Italiano IUCN e Ministero dell'Ambiente e della Tutela del Territorio e del Mare, Roma.

Samways M.J., 1994 - Insect conservation biology. Chapman and Hall, London.

Sahlen G. \& Ekkestubbe K., 2001 - Identification of dragonflies (Odonata) as indicators of general species richness in boreal forest lakes. Biodiversity and Conservation, 10: 673-690.

Siesa M.E., Padoa-Schioppa E., Ott J., De Bernardi F. \& Ficetola G.F., 2014 - Assessing the consequences of biological invasions on species with complex life cycles: impact of the alien crayfish Procambarus clarkii on Odonata. Ecological Indicators, 46: 70-77.

Suh A.N. \& Samways M.J., 2001 - Development of a dragonfly awareness trail in an African botanical garden. Biological Conservation, 100 (3): 345-353.

Sutherland W.J., 1996 - Ecological census techniques: a handbook. Cambridge University Press, Cambridge.

Wildermuth H., 1994 - Dragonfly and nature conservation: an analysis of the current situation in Central Europe. Advances in Odonatology, 6: 199-221. 
Appendix 1 - Species list. Species are marked as present (X), not found (-) or unconfirmed (?). Each species is followed by chorology (modified from Ottonello \& Oneto, 2013) and population trend in EU (Kalkman et al., 2010). Abbreviation for chorology and parks are the same showed in Fig. 2.

\begin{tabular}{|c|c|c|c|c|}
\hline SPECIES & Chorology & PNM & GV & EU trend \\
\hline \multicolumn{5}{|l|}{ Zygoptera } \\
\hline \multicolumn{5}{|l|}{ Calopterygidae } \\
\hline Calopteryx splendens Harris, 1782 & PAL-ES & $\mathrm{X}$ & - & Stable \\
\hline \multicolumn{5}{|l|}{ Lestidae } \\
\hline Chalcolestes viridis Vander Linden, 1825 & PAL-W & $\mathrm{X}$ & $\mathrm{X}$ & Stable \\
\hline Lestes sponsa Hansemann, 1823 & PAL-ES & $\mathrm{X}$ & $\mathrm{X}$ & Stable \\
\hline Sympecma fusca Vander Linden, 1820 & PAL-W & - & $\mathrm{X}$ & Stable \\
\hline \multicolumn{5}{|l|}{ Coenagrionidae } \\
\hline Coenagrion puella L., 1758 & PAL-ES & $\mathrm{X}$ & $\mathrm{X}$ & Stable \\
\hline Erythromma viridulum Charpentier, 1840 & PAL-SM & $\mathrm{X}$ & $?$ & Increasing \\
\hline Ischnura elegans Vander Linden, 1820 & PAL-W & $\mathrm{X}$ & $\mathrm{X}$ & Stable \\
\hline Ischnura pumilio Charpentier, 1825 & PAL-SM & $\mathrm{X}$ & $\mathrm{X}$ & Stable \\
\hline \multicolumn{5}{|l|}{ Platycnemididae } \\
\hline Platycnemis pennipes Pallas, 1771 & PAL-ES & - & $\mathrm{X}$ & Stable \\
\hline \multicolumn{5}{|l|}{ Anisoptera } \\
\hline \multicolumn{5}{|l|}{ Aeshnidae } \\
\hline Aeshna cyanea Müller, 1764 & PAL-W & $\mathrm{X}$ & $\mathrm{X}$ & Stable \\
\hline Aeshna isosceles Müller, 1767 & PAL-SM & $\mathrm{X}$ & - & Stable \\
\hline Aeshna mixta Latreille, 1805 & PAL-ES & $\mathrm{X}$ & $\mathrm{X}$ & Increasing \\
\hline Anax imperator Leach, 1815 & AFR-EU & $\mathrm{X}$ & $\mathrm{X}$ & Increasing \\
\hline Anax parthenope Selys, 1839 & PAL-Med & $\mathrm{X}$ & $\mathrm{X}$ & Increasing \\
\hline \multicolumn{5}{|l|}{ Gomphidae } \\
\hline Onychogomphus furcipatus L., 1758 & PAL-W & $\mathrm{X}$ & - & Stable \\
\hline \multicolumn{5}{|l|}{ Corduliidae } \\
\hline Somatochlora metallica Vander Linden, 1825 & PAL-W & $\mathrm{X}$ & $\mathrm{X}$ & Stable \\
\hline \multicolumn{5}{|l|}{ Libellulidae } \\
\hline Crocothemys erythraea Brullé, 1832 & AFR-EU & $\mathrm{X}$ & $\mathrm{X}$ & Increasing \\
\hline Libellula depressa L., 1758 & PAL-W & $\mathrm{X}$ & $\mathrm{X}$ & Stable \\
\hline Libellula fulva Müller, 1764 & PAL-W & $\mathrm{X}$ & - & Stable \\
\hline Orthetrum albistylum Selys, 1848 & PAL-W & $\mathrm{X}$ & $\mathrm{X}$ & Increasing \\
\hline Orthetrum brunneum Fonscolombe, 1837 & PAL-SM & $\mathrm{X}$ & $\mathrm{X}$ & Increasing \\
\hline Orthetrum cancellatum L., 1758 & PAL-W & $\mathrm{X}$ & $\mathrm{X}$ & Stable \\
\hline Orthetrum coerulescens Fabricius, 1798 & PAL-W & $\mathrm{X}$ & $\mathrm{X}$ & Stable \\
\hline Sympetrum fonscolombii Selys, 1840 & AFR-EU & $\mathrm{X}$ & $\mathrm{X}$ & Increasing \\
\hline Sympetrum pedemontanum Müller in Allioni, 1766 & PAL-ES & $\mathrm{X}$ & $\mathrm{X}$ & Stable \\
\hline Sympetrum sanguineum Müller, 1764 & PAL-ES & $\mathrm{X}$ & $\mathrm{X}$ & Stable \\
\hline Sympetrum striolatum Charpentier, 1840 & PAL-W & $\mathrm{X}$ & $\mathrm{X}$ & Stable \\
\hline Sympetrum vulgatum L., 1758 & PAL-ES & $?$ & - & Stable \\
\hline
\end{tabular}

